\title{
THE ROLE AND LINGUOPRAGMATICS OF FUNCTIONAL PARTS OF SPEECH OF THE UZBEK LANGUAGE IN THE LINGUISTIC SYSTEM
}

\section{Azamat Bakhronovich Pardaev}

Doctor of Philological Sciences, Professor, Department Of Uzbek Linguistics, Samarkand State University,Samarkand, Uzbekistan

\section{ABSTRACT}

Identify the role of function words in Uzbek language system, relation to content words, sources of enrichment and methods, historical and evolutionary development and determination of functional-stylistic and substantial-pragmatic features in speech. The aim of the papers is to define the status of the Uzbek language function words in the linguistic system, and to reveal their source and methods of enrichment, historical and evolutionary development, as well as functional-stylistic and substantial-pragmatic features.

KEYWORDS: - function words, word, morpheme, auxiliary, conjunction, particles, grammatical, functional parts, Uzbek language, pragmatic-stylistic analysis, functional-semantic features, discursive analysis.

\section{INTRODUCTION}

Today's researches in world linguistics being conducted on the basis of comparative-historical, systematic-structural and anthropocentric paradigms necessitates effective use of modern methods of analysis in solving problems of Uzbek linguistics. One of such urgent issues is the study of formal, substantial and pragmatic features of function words based on new scientific and theoretical views and methods. In world linguistics, explaining the functional specialization laws of independent words to functional words and revealing their pragmalinguistic, linguacultural, ethnolinguistic and psycholinguistic features are an important factor in the development of the field.
After achieving the country's independence, the further development of the native language, which is considered as the mirror of national traditions, has been raised to the level of the state policy. Preserving the native language, its enrichment, and necessity to work constantly on further enhancing its reputation has become a major issue of importance for our country's leader. Indeed, as our president pointed out: «First of all, nowadays, expanding the scope of application of the native language, learning deeply its historical roots and development of all aspects on scientific basis has become the most pressing issue»[1].

Thanks to independence Uzbek language has restored its reputation and has become one of the leaders among the Turkic languages [2]. Over the past several years many studies have been 
CURRENT RESEARCH JOURNAL OF PHILOLOGICAL SCIENCES 2(5): 103-

108, May 2021 DOI: https://doi.org/10.37547/philological-crjps-02-05-22

ISSN 2767-3758

(C)2021 Master Journals

\section{Crossref do) 81 Google}

Accepted25 ${ }^{\text {th }}$ May, 2021 \& Published 31 ${ }^{\text {th }}$ May, 2021

devoted on learning all stratums of our native language.In particular, we started to get rid of some Russian language standards imposed into our language grammatical structure.Uzbek language grammar was atoned from artificially "approximation" traits with Russian grammar. The certain successes were achieved in description of Turkish nature of our language, including the system functional wordscategories. However, we still do not have enough theoretical evaluation of functional words in our linguistics. Today, the generalization of these descriptions and interpretations on the basis of modern methodological principles, and evaluation of events based on new methods of scientific description has become a necessity.The views on these category words need theoretical development. The solution of this problem was not found yet not only in Uzbek linguistics, but in World linguistics as well, and it still remains the most disputed issue.Therefore, based on the recent achievements of functional words in world linguistics, according to the internal laws of our language, their classification and functional-semantic and pragmatic substantsial study is one of the most important issues of modern Uzbek linguistics.

It should be pointed out, as of today, functional word in Uzbek linguistics were described according to formal analysis principles. Nowadays, the formal analysis together with substantial interpretation principles - linguistic system and linguistic units are considered as good opportunities, and understanding these opportunities as an internal conflict integrity arising from various relations of linguistic unit is becoming a trend.In addition,irrespective of the fact if functional words are in linguistic phase or in speech phase, they were studied on the descriptive basis, so far seperate from the principles of static linguistic analysis activity and from speech process.Today, in our linguistics the pragmalinguistics - based on the principles of discursive analysis of language and speech units, the comprehensive analysis of pragmatic and stylistic characteristics during communicative speech process is becoming widely popular. Although, as of today there were several research works devoted to semantic-methodological characteristics of functional words, however, they missed the following: semantic common, functional limitations, discursive semanticstylistic parallels and differences, mutual exchange and there was no single source of studying contradiction cases with each other, substantiality connected with pragmatism in monolithic monographic form. In Uzbek language there are three types of approaches based on new methodological principles related to linguistic role and speech events of functional words - evaluation of previous, factual materials with the new criteria determines the relevance of the research.

Starting with century linguistics as a result of the global gain pragmalinguistic, culturalinguistic, psycholinguistic influences function words were also examined from the point of view as a means of acting on the human psyche his cognitive world. For example, in the framework of the International Grant of the National Institute of Health MN 59321 linguists University of Pennsylvania and Ch.Sindi Dzh.Pennbeyker exploring the psychological characteristics of function words justified as the primary means of mental state of the person in the process of speech relationships [3]. Project participants of the European Council ERC-2011-AdG-295810 M.Zhonson (Sydney), E.Kristoff (Paris), D.Katrin (New Mexico), D.Emmanuel (Paris) in the study of function words studied voice paradigmatic forms, the ability to ability selection of function words when speech communication as one of the defining features of the intellectual development[4]. Since the 90 years of the twentieth century, fundamental research function words linguists Beijing University, 
CURRENT RESEARCH JOURNAL OF PHILOLOGICAL SCIENCES 2(5): 103-

108, May 2021 DOI: https://doi.org/10.37547/philological-crjps-02-05-22

ISSN 2767-3758

(C)2021 Master Journals

\section{Crossref do) 81 Google}

Accepted25 $5^{\text {th }}$ May, 2021 \& Published 31 ${ }^{\text {th }}$ May, 2021

which analyzed more than ten thousand words of Chinese language support as lingvokulturemy and created for learners of the language facilities[5] Ch.Naoko linguist Sophia University Tokyo, described more than seventy speech loads as decoration and compared with two hundred turns of phrase in the English language[6].

A number of studies were undertaken around the world to identify the lexical-grammatical and functional-semantic characteristics of function words. Among them are noteworthy the researches done by G.Kreydlin on Russian, A.Gereeva on Kumik and English, F.Ozdoeva on Nakh, T.Nikolaeva on Slavic, Z.Musaeva on Dargin, Kh.Sultonbaeva on Bashkir, N.Manafov on Azerbaijan, F.Kenjebaeva on Kazakh and F.Zeynalov on many Turkish language function words.

Researches were carried out on function words in Uzbek linguistics as well, and their results were reflected in generalizing descriptions of our language structure, scientific grammar and dictionaries, and educational literature designed for various sectors of the education system. These descriptions were mainly based on traditional linguistic methods widely practiced in the 20th century. Particularly, this issue was thoroughly investigated in the works of A.Kononov, Sh.Shoabdurahmonov, H.Berdiyorov, J.Mukhtorov, R.Rasulov, T.Rustamov, O.Bozorov and D.Urinbaeva. During the years of independence, a number of dissertational researches on functional-semantic and pragmatic analysis of function words have been carried out. Particularly, a certain aspect of function words was illuminated in the studies of such linguists as U.Rahimov, T.Turdiboev, Z.Isakov and Z.Burkhanov.

However, the lack of a general and special study of a number of issues related to the need for theoretical development of views about function words in our linguistic, the widening of not only semantical and grammatical but also functionalstylistic and substantial-pragmatic capabilities of these units, their going beyond the grammatical status and becoming important stylistic means from simple information to sensibility and from abstractness to exactness, the activeness in the process of speech (discourse), functional restriction, pragmatic and stylistic features requires a monographic study of this subject.

The following approaches were used in the works dedicated to functional words: 1) from word as a seperate part of speech, 2) functional words as a tool between vocabulary and grammar, 3) functional word as a tool for decribinggrammatical meaning, 4) functional words as an object of stylistics.

The following methods were applied to cover the research subject:

- - comparative-historical method(origin of functional words ( etymology), development, its relations with content words during research process);

- method of synchronous formal description (determine the content of functional words categories, types of units structures, types of speech meaning);

- comparative method (compare different generalities during process of determining similarity principles and differences);

- method of distributive analysis (during process of detremining additional and contradictory distribution in generalities);

- substantial analysis method (in determining gradual and other types of paradigmatic relations, general (linguistic) and private (speech) meaning relations);

- discursive analysis method (during the process of determining pragmatic meanings of functional words structures in 
CURRENT RESEARCH JOURNAL OF PHILOLOGICAL SCIENCES 2(5): 103-

108, May 2021 DOI: https://doi.org/10.37547/philological-crjps-02-05-22

ISSN 2767-3758

(C)2021 Master Journals

\section{Crossref do) 81 Google}

Accepted25 $5^{\text {th }}$ May, 2021 \& Published 31 ${ }^{\text {th }}$ May, 2021

discourse (in speech communication considered as an activity);

- from statistical methods (during the process of determining speech frequency of some events).

Using example of functional words categories, mutual connection of obtained descriptions by methods of formal, substantial and discursive analysis of linguistic units, and it was proved that we could use methods of ensuring the continuity in other language units' decription as well;

new approach, that is, the learning methodics of functional words interlinked with formal, substantial and discursive analysis was worked out and practically implemented in the definition of concrete cases in Uzbek language;

As a result of application of formal, substantial and discursive methods together, in the concluding table of research "Content of functional words categories in Uzbek language and their substantial-pragmatic description" functional words of Uzbek language were structurally classified as a task-form and their close parameters were identified.

The scientific novelty of the research is as follows: substantial-pragmatic characteristics of function words were identified by means of formal, substantial and discursive analysis methods;

the formation stages and functional-semantic features of function words in the Uzbek language were revealed;

the adoption of function words as words by native speakers and their grammatical function were substantiated;

a special role of grammaticalization phenomenon in transitioning independent lexemes to function words was established, and their general and specific grammatical meanings were clarified, suggesting that these units are in the intermediate third place in the «word» «morpheme» adversative;

the transition of functional parts of speech (auxiliary to conjunction, conjunction to particle, particle to conjunction) was substantiated, and the presence of a presuppositive sign in these units was identified;

as a result of applying formal, substantial and discursive analysis methods together, the function words were structurally classified in terms of form and task, and were based on about ten parameters;

it was proved that function words express different pragmatic meanings in the text to expose the author's creative intentions, and it was substantiated that particles have a new task as «reviving» the text, and giving it a spirit of discourse;

as a result of the expansion of communicative opportunities of the Uzbek literary language, it was revealed with definite examples that, along with all the parts of speech, function words also contain new units increasing their grammatical and pragmatic possibilities; the differentiation of function word formations was analysed, proving in them the manifestation of the process of pragmatic specialisation based on synonymy.

It was proved by examples, that functional words express various pragmatic subjects connected with uncovering illocutionary goal of the text's author. Reviving new text in particles, forming a task of attaching discourse spirit to it and development of new types of particles discursive particles were substantiated.

During independence years in the process of specialization of functional words the new sectorial directions were formed and developed, and their close linkages were described by examples. Also, the differentiation of formations out of functional words was analyzed and based on meaning it was proved that their pragmatic 
CURRENT RESEARCH JOURNAL OF PHILOLOGICAL SCIENCES 2(5): 103-

108, May 2021 DOI: https://doi.org/10.37547/philological-crjps-02-05-22

ISSN 2767-3758

(C)2021 Master Journals

\section{Crossref do) 81 Google}

Accepted25 $5^{\text {th }}$ May, 2021 \& Published 31 ${ }^{\text {th }}$ May, 2021

specialization process was going on.

it was substantiated that the results shown in the table of the «tructure and substantial-pragmatic characteristics of functional parts of speech in the Uzbek language» give important scientifictheoretical information for Uzbek linguistics, which reflects more than 10 ontological features like historical and etymological affiliation of each of more than 600 function words used in the current Uzbek language, their purity or functionality, the part of speech they originated from in functional auxiliaries, their grammaticalization level, part of speech, semantic-functional type and group membership within the part of speech, forms, one or more functionality, association with adjacent parts of speech, scope of use, methodical setting, lack or presence of an inherent presuppositive sign; that they serve for the improvement of textbooks and manuals in such subjects as language history, stylistics, text linguistics and theory of linguistics;

in the course of the research, it was defined that if the stylistic activity of function words creates diverse meaning in the communication process, the pragmatic (discursive) aspect gives additional information (tendency, meaningfulness, positiveness, negativeness, doubt, confidence, emphasis, naturalness, strangeness, etc.) about the speech situation and condition, the psychological state of the speaker and the listener, the open and secret intentions and attitudes;

it was determined which part of speech the functional auxiliaries originated from and which stage of grammaticalization (yordamchisimonlik, yordamchilashayotganlik, yordamchilashganlik, tublashganlik) they stood at;

the role in the process of language evolution and morpheme formation of the configuration trio «independent word $\rightarrow$ function word $\rightarrow$ suffix» in the Altaic languages was determined; the main (primary) and adjacent (secondary) functions of auxiliary words were identified, and recommendations were drawn up on the scope of their usage and pragmatic features;

in the tables containing the results of the research, the relative composition of function words (auxiliary, conjunction, particles) was reflected; their important practical role in mother tongue teaching and students' oral speech was revealed by explaining their role, significance, formal, substantial and pragmatic features in the language and speech.

In studying semantic and grammatical structures of functional words in world linguistics, the research is conducted in the following priority areas: identify the role of functional words in linguistic system; identify statistics of functional words in certain language;substantiation of the process of functional words origin and their grammaticalization; determine interlanguage transposition; analyze pragmalinguistic, linguoculturological, psycholinguistic features; determine the role of functional words during speech communication process.

\section{REFERENCES}

1. http://www.uza.uz/documents/alishernavoiy-nomidagi-toshkent-davlato'zbek-tili-va-adabiyoti-13-05-2016

2. Mahmudov N., Begmatov E. Our language's yesterday and today // Uzbek Language and Literature.Tashkent, 2010. -№5.-B.9-15.

3. Pennebaker, DJ. CH.Chung. The Psychological Functions of Function Words / Philadelphia: Linguistic Data Consortium, University of Pennsylvania / http://homepage.psy.utexas.edu / homepage /faculty/ pennebaker/ reprints/ Chung\&JWP.pdf .2014. 
CURRENT RESEARCH JOURNAL OF PHILOLOGICAL SCIENCES 2(5): 103-

108, May 2021 DOI: https://doi.org/10.37547/philological-crjps-02-05-22

ISSN 2767-3758

(C)2021 Master Journals

Crossief do) 88 Google

Accepted25 ${ }^{\text {th }}$ May, 2021 \& Published 31 ${ }^{\text {th }}$ May, 2021

4. http://

www.lscp.net/persons/dupoux/papers

/Johnson_CDD_2014_function_words_

improve_unsupervized

_word_segmentation.ACL.pdf

5. http://www.aolifo.de/ Lectures of

Function Words of Contemporary

Chinese Language /现代汉语虚词讲义 /

Peking University Press. 2005.

6. www.kodanshausa.com/authors/65... 